\title{
HEARTS OF DARKNESS: THE EXPERIENCE OF 'HORROR' IN ROGER CASEMENT'S WRITINGS - THE FABRICATION OF AN ANTIHERO $^{1}$
}

Roberto Carlos de Andrade ${ }^{1^{\star}}$

\author{
${ }^{1}$ Universidade Federal de Roraima, Rio Branco, Roraima, Brasil
}

\begin{abstract}
The article presents an analysis of texts by a number of authors who deal with Roger Casement's writings, aiming at assessing how those authors fabricate a discourse based on alleged acts a discourse that ends up perpetuating a representation of Casement's persona. Casement ends up being both a hero - up until his arrest and condemnation as a traitor to the British Empire - and an antihero - not only after his arrest but also and especially after his Black Diaries were uncovered, bringing about Casement's disappearance from the public's view as an important humanist and character in British and Irish histories. The article also tackles the close relation between Casement and the main characters in Joseph Conrad's Heart of Darkness.
\end{abstract}

Keywords: Roger Casement; Antihero; Ireland; Joseph Conrad.

\footnotetext{
Possui graduação em Letras, Licenciatura em Português, Inglês e Literaturas Correspondentes pela Universidade Federal de Santa Catarina (1991), mestrado em Letras (Inglês e Literatura Correspondente) pela Universidade Federal de Santa Catarina (1994) e doutorado em Letras (Inglês e Literatura Correspondente) pela Universidade Federal de Santa Catarina (2003). É professor associado da Universidade Federal de Roraima, onde atua desde 1994. Tem experiência na área de ensino de Língua Inglesa e Literatura Correspondente com ênfase em Literaturas Norte-Americana e Britânica contemporâneas. Seu e-mail é rc.andrade1964@bol.com.br. ORCID: 0000-0002-0291-6376.
} 
"EACH one of us is, successively, not one but many. And these successive personalities that emerge one from the other tend to present the strangest, most astonishing contrast among themselves." José Enrique Rodó, Motives of Proteus.

With the exception of historians and researchers interested in Ireland's twentieth-century history, Roger Casement remains a name not widely known in Brazil, despite his close relation to our country. Even his historical relevance, according to some sources, is yet to be assessed, especially when one reflects on his role in revealing the intricacies of the outset of WWI, due to his allegiance to the Germans. As a British consul in Brazil, his trips to our country, as well as his importance in the outcome of Congolese history in the turn of the twentieth century, have been extensively documented and discussed.

Casement's appeal as an intriguing, instigating, even enigmatic character is ripe with contradictions and has, in recent years, been the subject matter of a documentary - "The Ghost of Roger Casement," by Alan Gilsenan, in 2002; a novel - The Dream of the Celt, by Mario Vargas Llosa, in 2010; a play, namely As duas mortes de Roger Casement, by Domingos Nunez, in 2016; as well as a graphic novel, "The Trial of Roger Casement," by Fionnuala Doran, in 2016. With the celebration of the Easter Rising centenary - a rebellion determinant to Ireland's Independence - Roger Casement's name came to therefore once again.

A range of scientific evidence has been collected after Casement's death with the specific purpose of proving the authorship of the Black Diaries ${ }^{2}$ and the authenticity of the homosexual acts therein portrayed, all aimed at degrading and denying Casement a heroic stature. However, what interests me most in this essay is the war of words undertaken in order to achieve such questionable objective. I am also interested in how Casement's discourse has been used and manipulated to sustain a biased agenda to portray him as an antihero, according to Victor Brombert's views on the subject in his In Praise of Antiheroes: Figures and Themes in Modern European Literature. Moreover, I apply Tzvetan Todorov's views on intertextuality - found in Mikhail Bakhtin: The Dialogical Principle - in order to contextualize the intricacies of the aforementioned manipulation. Casement's reports and diaries cannot be read separately, since they are manifestations of the same persona, of the same author and subject. In that sense, instead of proofs or "authenticity", I am more interested in the representations afforded by the author's discourses; i.e., from the discourses raised by the words written by Casement himself. I have investigated the power and importance of a demoralizing and normalizing apparatus forged in an attempt to erase the presence of a persona-non-grata.

In other words, I am interested in assessing how authors fabricate a discourse based on alleged facts in order to perpetuate a representation of Casement's persona both as a hero - up until his arrest on April 21, 1916 - and as an antihero - not only after his arrest but also and especially after his Black Diaries were uncovered. The fact that those diaries were revealed even before Casement's execution, contrary to 
his wishes, brought about not only his own disappearance from the public's view as an important humanist and character in British and Irish histories, but also the emergence of highly negative aspects of British government and society.

In tune with Angus Mitchell's arguments in his attempt to prove that Casement's Black Diaries are the product of a forgery, one is prone to detect a clear process of fabrication of Roger Casement as an antiheroic figure. The discourses produced from the reading of the Black Diaries are responsible for the alleged elimination of his name from the history of Ireland as one of the main martyrs of the Easter Rising. According to Mitchell in the Preface to The Amazon Journal of Roger Casement, his own attitude towards the Black Diaries has changed over the years:

There now seemed no need to publish them unless one wished to throw oil on the fire. They have poisoned the reputation of Casement and muddied the waters of South American history. To publish them only serves to inspire more hatred and create more public confusion over a serious issue. (8-9)

Ultimately, Mitchell points out that Casement's character "was seen as 'flawed' due to his treacherous support of Germany, his eleventh hour conversion to the Catholic Church and his sexuality..." (The Amazon Journal of Roger Casement 24). By "his eleventh hour", the author means that his conversion was effected at the last possible moment.

Most of the recent texts about Casement are historical, emphasizing his importance in the history of Ireland and his denunciation of and struggle against the atrocities committed in the Congo and in the Amazon region of Putumayo, respectively in the late nineteenth and early twentieth centuries. Even in those texts, however, the author's sexuality almost always appears as a background to explain a suspected conspiracy perpetuated by the British and Irish governments to degrade his name in order to avoid his being seen as a martyr. That background is what ultimately is of interest in this essay, in that I have assessed in what manners aspects of new discourses are crossed with Casement's own discourse.

One disturbing aspect of some authors' texts that tackle Casement's sexuality is that they treat his alleged homosexual activities in an apologetic tone, in the sense of creating excuses for his acts, as though in spite of his sexual preferences, he was a good man. Roger Sawyer, for one, tries to answer his own question of why Roger Casement is a flawed hero saying that " $\mathrm{t}]$ he key to the answer... lies in the conditions of the Consular Service, which brought out the best and the worst in [him]" (The flawed hero 145). In a surprisingly superficial psychological turn, he attempts a further explanation:

There is little doubt that initially the effect of family tensions on the youngest orphan helped to produce the deviation from the sexual norm which accustomed him to commit frequent and illegal acts over many years... Another aspect of his sexual activities was that, with only one 
recorded identifiable exception, all his partners, regardless of nationality, were of the lowest social class. (The flawed hero 145)

Sawyer's biased contributions go even further, and he submits that Casement's achievements in the Consular Service "were the substantial compensations for the inner sufferings of an individual flawed to a certain degree by a combination of social, political, religious and, above all, familial stresses in his formative years" (The flawed hero 146). As a consequence, "[t]he peculiar circumstances of his childhood... initiated, in a classic way, the search for alternative sources of affection" (The flawed hero 30). George Bernard Shaw himself, in a February 11, 1937 letter to the Irish Press, had already hinted at the psychological implications of Casement's plight: "The trial occurred at a time when the writings of Sigmund Freud had made psychopathy grotesquely fashionable. Everybody was expected to have a secret history unfit for publication except in the consulting rooms of the psychoanalyst" (qtd. in Mitchell, The Amazon Journal of Roger Casement 20).

The fact that the Black Diaries have been considered a forgery used as a tool within a conspiracy to demoralize Casement shows in itself a biased way to approach the writings, since it denotes the preconceived view that an honorable man would never go as low as to write in a confessional vein the abominations contained in those writings. According to Sawyer,

The obsessive quality of the erotic details has alienated many. Perhaps some of it is fantasy; but even that diagnosis can hardly excuse the man in the eyes of would-be admirers. All it does is confound those who argue that the scenes described could not possibly have gone undetected in such places as Iquitos... (Roger Casement's Diaries, 1910: The black \& the white 3)

For Sawyer, what he calls Casement's case is not impossible to believe in, since

whilst addicted to homosexual practices, he did little to resist them; like a drug, they seemed to bring their own particular consolations. Moreover, in the climate of opinion of the day, it was easy - unless one were caught in the act - to divorce one's principles from one's practices; or simply to rationalize one's actions by stating, as R.C. did to his defending Counsel, that such inclinations were inseparable from genius. (Roger Casement's Diaries, 1910: The black \& the white 91)

Coming from a mixed family, Casement was exposed to constant paradoxes and a nomadic childhood, due to his father's military obligations. This fact has enabled Sawyer to compare Casement's life story to Ireland's own history (The flawed hero 1). To begin with, his mother - who died when he was nine - was a Roman Catholic, and his father - who passed away when he was thirteen - was a Protestant. Thus, even though Casement lived his whole life as a Protestant, eventually - when he was waiting for his sentence in April 1916 - he was converted to Catholicism, which was possible because his mother had secretly baptized him - along with his siblings - when he was a child. Besides, his own father 
was a model for him in terms of nationalism, defining an intriguing similitude between both men's ambiguous trajectories in life: loyal to the British Empire due to professional obligations, they never relented their love for their country and advocated its independence. According to Sawyer, "[Casement] seemed to find no difficulty in being both an Irishman and an imperialist..." (The flawed hero 2).

Casement's first contact with the paradoxical nature of the European presence in African regions with the purpose of "civilizing" the natives happened in 1892, when he was sent as an employee of the British Consular Service to the region nowadays know as Nigeria and later to the Congo Free State. For the next decade, he was to witness and denounce - by way of his 1904 report to the Houses of Parliament - the violence to which the natives were victim due to what he assessed to be a system of exploitation of the local workforce in the rubber Company under direct orders of the Belgian King, Leopold II (Sawyer, Roger Casement's Diaries, 1910: The black \& the white 29-30).

His close relation with Brazil started in 1906, when he spent two years first in Santos and then in Belém - before accepting the post of Consul-General of Britain and Ireland in Rio de Janeiro. From there, in 1910, he was to have a decisive role in denouncing the atrocities committed in the Putumayo River region, in Peru:

The atrocities... were even more horrifying than those which Casement had exposed in Africa. Tribal peoples had been enslaved by means of the local system of debt-bondage: peonage [...and] were committed in the name of a British-registered company. (Sawyer, Roger Casement's Diaries, 1910: The black \& the white 31)

It was especially Casement's reports to the British Government that ignited a campaign against the inhuman system of exploitation of the natives. From all of these experiences, Casement's anti-imperial feelings started to manifest themselves. In a 1904 letter to Alice Stopford Green, he wrote: "I knew well that if I told the truth about the devilish Congo conspiracy of robbers I should pay for it in my own future, but when I made up my mind to tell, at all costs, it was the image of my poor old country stood first before my eyes (sic)" (qtd. in Mitchell, The Amazon Journal of Roger Casement 98).

A close parallel between Roger Casement and the main characters in Joseph Conrad's Heart of Darkness, especially in what concerns the 'Horror' denounced by Kurtz, can be convincingly traced. The life experience exposed in Casement's reports and especially in his diaries can be directly compared to the experience of 'horror' evidenced by that character. Some scholars have already pointed out Casement and Conrad's close relation, especially Angus Mitchell and Michael Taussig - in Shamanism, Colonialism, and the Wild Man: a study in terror and healing - comparing their trajectories in the Congo and reporting their mutual influence - actually, they eventually met and became friends. The denouncing and humanistic aspects of both men's writings is what approximates their role in literary terms. In fact, in 16 Lives: Roger Casement, Mitchell proposes one 
question: "Might Casement's own transformation from a decorated agent of empire into unrepentant republican revolutionary mirror Mr Kurtz's own rejection of the empty spectacle of civilization?" (The Amazon Journal of Roger Casement 6). After that, however, Mitchell depicts three distinct impressions from Conrad concerning Casement:

It is interesting that over the years Conrad came to revise his view of Casement in line with public perceptions of the man. Conrad's Congo Diary recorded their initial meeting: "13 June $1890 \ldots$ Made the acquaintance of Mr. Roger Casement, which I should consider as a great pleasure under any circumstances and now it becomes a positive piece of luck. Thinks, speaks well, most intelligent and very sympathetic." (The Amazon Journal of Roger Casement 47)

Later, in a 1903 letter to RB Cunnighame Graham, Conrad adds what Mitchell calls “.... revealing series of inserted details: '... He's a Protestant Irish, pious too. But so was Pizarro. For the rest I can assure you that he is a limpid personality. There is a touch of the Conquistador in him too..."' (The Amazon Journal of Roger Casement 47-48). Finally, in 1916, amidst the turmoil of Casement's imprisonment and as the man waited for his trial, Conrad writes to John Quinn that Casement

had now become "a man, properly speaking, of no mind at all. I don't mean stupid. I mean that he was all emotion... But in the Congo it was not yet visible... the work he was busy about then was recruiting labour... I went with him several times on short expeditions to hold 'palavers' with neighboring village-chiefs'. (The Amazon Journal of Roger Casement 48-49).

As Mitchell surmises, "Conrad's evolving view of Casement reveals the complex politics of remembering him, and the instability of memory that took some quite dramatic turns once his revolutionary sympathies were revealed" (The Amazon Journal of Roger Casement 49). Moreover, the fact that Conrad now perceived Casement as being "all emotion" reminds us of Johanna M. Smith's feminist reading of Heart of Darkness, in that "Marlow's construction of... women dramatizes the point of his story, its manful effort to shore up an ideology of imperialism with an ideology of separated spheres" (qtd. in Conrad 177) concerning gender relations. It is as if Conrad's response to Casement's confusing persona was influenced by what Smith calls "separated spheres", i.e., there is an "exclusively masculine sphere of experience and truth" (qtd. in Conrad 179) from which women are isolated by a system of discourses. Marlow's response to his ant's imperialistic rhetoric is to debase it as "sentimental pretence".

The close relation between Casement and Conrad is one of the most important themes in ethnologist Michael Taussig's Shamanism, Colonialism, and the Wild Man: a study in terror and healing, first published in 1987. Taussig, however, relates Casement to the 'terror' in Conrad's novella in a more physical 
sense, i.e., relating the horrors witnessed by both authors. In this essay, I would like to emphasize the discursive or social aspect of the 'horror' - especially from Kurtz's point of view - in the sense of a lack of communication between cultures separated by an immense historical abyss. Furthermore, I would like to extend the experience of 'horror' to Casement's own destiny: being exposed due to his compulsion to writing, especially if we believe in the Black Diaries' authenticity, he also ends up being the victim of an impossibility of communication between the officializing Western discourse and his own parallel discourse - exposed as marginal and relegated to oblivion.

According to some sources, Casement was aware of the conflicting aspect of his own discourse, of the incompatibility of the two discourses; in fact, the censoring aspect of his own official diaries was detected by Roger Sawyer in his introduction to Roger Casement's Diaries, 1910: The black \& the white:

...one must imagine Casement in his role as Consul-General occasionally checking a detail in his secret personal diary as he writes a fuller, official, version eventually intended to form the basis of a published work... Great care had to be taken to ensure that details from the Black Diary were not inadvertently incorporated into the white. (3)

Arguably, perceiving the marginal and subversive character of his own writing, Casement relegates it to silence - his personal belongings, where the Black Diaries were found, were not to be revealed until one hundred years after his execution. The Casement of the Black Diaries cannot coexist and cannot have voice or space in the writings of the other Casement - the humanitarian hero. In that sense, Casement encompasses in a single character nuances from Conrad's Heart of Darkness's main characters: Marlow and Kurtz. At the same time as he just like Marlow - acts as a witness, investigator and denouncer of an extremely cruel and inhuman system, Casement does not avoid an intense physical and psychological relationship with the natives - just as Kurtz does in the Congo. Marlow is a highly ambiguous character, since he has the specific mission of exposing Kurtz as a criminal acting against the Company - and, by extension, against the British Empire - but ends up sympathizing with Kurtz and his agenda. He is ultimately unable to tell Kurtz' unnamed 'Intended' the truth when he returns to civilization: notoriously, when asked by her what Kurtz's last words were, Marlow lies and says: "The last word he pronounced was - your name" (Conrad 94). Interestingly enough, in Smith's feminist reading, "by substituting the Intended's name for 'the horror' [Marlow] equates the two; her ignorance of this equation becomes a punishing humiliation" (qtd. in Conrad 181). Once again, we can see Casement being related to the powerless sphere reserved for women; in fact, he ends up being even more ambiguous than Marlow - some authors point to the duplicitous aspects of his persona - especially concerning his allegiance to the British Empire. From any of the biographical texts available, one can easily surmount how he progressively transforms himself from "loyal British diplomat to treacherous Irish rebel" (Harris 138). 
The direct comparison to Conrad's Kurtz works not only as an illustration but also and especially in terms of an analogy considering each of the characters involved in their own specific contexts, evaluating their proximities in bordering situations. What happens to Casement is that he is debunked from the position of the national hero due to the manipulation of the authorities, who allegedly use his Black Diaries to demoralize him. The relation with Conrad's Kurtz is present again due to the negative aspects of both cases, i.e., how both characters become antiheroic and anti-imperialistic. What lie in the center of the demoralizing process are acts considered as degenerate and illegal, not in accordance with the condition of the hero. Just as we perceive Kurtz, we can see Casement as a witness of shocking and inhuman facts that become known due to his own public reports, but the marginal character of his personal records is ultimately used to conceal any relevance of his humanistic acts.

Furthermore, Casement's life seems to be in accordance to what Taussig calls the "space of death":

a death-space in the land of the living where torture's certain uncertainty fed the great machinery of the arbitrariness of power, power on the rampage - that great steaming morass of chaos that lies on the underside of order and without which order could not exist. (4)

According to Taussig, the "space of death" functions "as a threshold that allows for illumination as well as extinction. Sometimes a person goes through it and returns to us, to tell the tale" $(1991,4)$, which is exactly what happens in Heart of Darkness. In a final analysis, these spaces of death "blend into a common pool of key signifiers binding the transforming culture of the conquerer (sic) with that of the conquered" (5). In his comment on Taussig, right after stating that "The Amazon Journal is linked most directly to the heart of darkness and the conflict between civilization and savagery", Mitchell points out that

Taussig makes a convincing connection between Casement and Joseph Conrad's Heart of darkness. When reading Casement's Amazon Journal it is hard not to draw parallels with this extraordinarily powerful metaphysical work describing a river journey in search of the darkness at the heart of the white man's civilization. (The Amazon Journal of Roger Casement 52)

According to Victor Brombert, "[the] bordering lines between the heroic and the non-heroic are blurred" (14). The antihero mode "implies the negative presence of the subverted or absent model" (14). Always exposing the intrinsic connection between the two models, Brombert considers the antihero as a "negative hero", tracing a negative aspect to heroism itself:

A somber view seems to prevail in the fictional works in which the hero is associated to a world of darkness and transgression. Joseph Conrad's 
Heart of darkness not only provides an exemplary title and a key figure who gives in to the temptation of 'transposing the borders of the invisible', but also suggests that the 'darkness' is the privileged domain of the heroic soul. (18)

The strong heroic aspects of Casement's deeds and trajectory have already been tackled in "From the Putumayo to Connemara: Roger Casement's Amazon Voyage of Discovery" (2002), by Peter James Harris, in which the author compares the months spent by Casement in South America to a kind of "homecoming", arguing that that period represents a crucial phase in Casement's process of identification with his Irish nationality: "It therefore seems appropriate to describe Casement's Voyage to the Putumayo as an odyssey, for it combines the elements of the heroic, the homecoming and the duplicitous in equal measure" (132). Hence, once more, one might relate Casement to the antihero view advanced by Brombert, according to whom, in the twentieth century, "the heroic model - actually the very notion of a model - has been subverted... Such characters may appeal to our imagination and even appear as admirable, by the way they help to annul, subvert, and contest an 'ideal' image" (19).

According to Tzvetan Todorov's in The Dialogical Principle - a study of Mikhail Bakhtin's dialogical principle -

[T] he utterance is the product of a working up, in which linguistic matter is but one of the ingredients; another is all that is brought to a verbal production by the fact of it being uttered, that is, its unique historical, social, cultural context. (26)

Furthermore, Todorov relates Bakhtin's dialogism to the intertextuality inherent to any discourse:

...all discourse is in dialogue with prior discourses on the same subject, as well as with discourses yet to come, whose reactions it foresees and anticipates. A single voice can make itself heard only by blending into the complex choir of other voices already in place. (x)

It is only under the light of new interpretations and discursive relations that Roger Casement's importance and - most of all - his presence can be reassessed and reassured in future historical and literary discourses.

The highly abstract character of the term impedes Todorov or Bakhtin to reach a definition or a closed concept for discourse; however, both authors emphasize the role of the social aspect involved in any discourse: "Language, discourse: that is almost the totality of human life" (24). Besides,

Meaning (communication) implies community. Concretely, one always addresses someone, and that someone does not assume a purely passive role...: the interlocutor participates in the formation of the meaning of the 
utterance, just as the other elements - similarly social - of the context of uttering do. (30)

Furthermore, "[t]here is no first or last discourse, and dialogical context knows no limits (it disappears into an unlimited past and in our unlimited future)" (110). According to Todorov, Bakhtin differentiates text from language in that the latter, being a system of signs, is opened to translation, whereas the former, being a system of meanings, can never be fully translated, since there cannot be a unification of meanings. The text, just as the discourse, always depends on the location and time of utterance, i.e., its social or ideological context (26). Hence, we see that the manipulation of a discourse and the resistance to such manipulation can make or break, construct or destroy one's persona or ideas. That is what ultimately happens in Casement's case.

It is controversially ironic that the very reason why Casement was refuted and rejected as a martyr is exactly the reason why he is lauded more than one hundred years later. By the time he was executed, the current thought and reaction to his practices were of revulsion and astonishment. He was abandoned, isolated and left to die as a mentally diseased person, worthy of the worst treatment and feelings. Not even his past humanistic activities were able to prevent the hatred that society ultimately showed. As Sawyer puts it,

[h]atred of the prisoner reached a peak of intensity which has seldom been equaled in England. One unique outcome of it serves to illustrate the nature of the reaction against him: his is the only entry in Who's Who which has not been carried forward to Who was Who after death; he became therefore, in a sense, the first and, as far as is known, the only non-person of the western world. (The flawed hero 142)

Historically, Taussig remembers that "[t]he day after the trial finished the News of the World claimed that nobody who saw [the black diaries] 'would ever mention Casement's name again without loathing and contempt"' (14). One might say, along with Taussig, that after the execution Casement's persona has achieved the space of death, the space to which he himself had relegated his homosexual manifestations throughout his life and from which a counterhistory or a counterdiscourse is possible. Casement's enemies also knew how to use those manifestations in order to put him in his due space. According to Mitchell,

Once Casement's treason had been identified, the challenge to the British authorities was intricately bound up with controlling his narrative. In the century that has passed since his death, it is evident that an internal policy was evolved whereby Casement's story was framed and manipulated for public consumption. (16 Lives: Roger Casement 354)

One of the ways of reassessing Casement's role in Ireland's recent history is to reread, analyze and divulge the political implications of his writings. Mitchell 
alerts us that " $[\mathrm{h}]$ is political writings had forthrightly accused leading politicians of the age... of instigating a deliberate strategy to deceive the British people and of involving the world in a war that was the consequence of a decade of democratically unaccountable secret diplomacy" (16 Lives: Roger Casement 352). Mitchell is especially referring to two of Casement's most important writings: "The far-extended baleful power of the lie", first published in The Continental Times in November 3, 1915, and The crime against Europe; a possible outcome of the war of 1914, first published in 1915.

As Mitchell suggests, "Casement's wider concerns about the fate of humanity and his relevance to modern Ireland have been conveniently obscured by an enduring and ultimately pointless anxiety about his sexuality" (16 Lives: Roger Casement 17). In fact, disturbing what Mitchell called "the complex politics of remembering" Casement, "The Black Diaries continued to be deployed to subvert [his] moral authority and his denunciation of the system by locking public understanding inside a futile discussion on his sexuality" (16 Lives: Roger Casement 371). I agree with Mitchell, but I also contend that all the discussion involving Casement's sexuality adds an extra hint of subversiveness to his story, which culminates in his being held as one of the first Irish gay icons.

Notes

1. This article is the result of a post-doctoral research under the guidance of Professor José Roberto O'Shea, $\mathrm{PhD}$.

2. It has become a sort of consensus amongst Casement's researchers to use the expression "black diaries" specifically to refer to the three diaries for 1903, 1910, 1911 and a ledger for 1911, which comprise the texts used to demoralize the man in front of his friends, admirers and the public in general during his trial for participating in the Easter Rising.

\section{References}

Brombert, Victor. In Praise of Antiheroes: Figures and Themes in Modern European Literature, 1830-1980. The University of Chicago Press, 2002.

Conrad, Joseph. Heart of Darkness. Case Studies in Contemporary Criticism series. Bedford Books, 1996.

Harris, Peter James. "From the Putumayo to Connemara: Roger Casement's Amazon Voyage of Discovery". ABEI Journal: The Brazilian Journal of Irish studies. No. 4, Jun. São Paulo: FFLCH/USP, 2002. pp.132-139.

Mitchell, Angus. The Amazon Journal of Roger Casement. Anaconda Editions and Lilliput Press, 1997.

16 Lives: Roger Casement. Dublin: The O’Brien Press, 2013.

Rodó, José Enrique. Motives of Proteus. Gordon Press, 1977.

Sawyer, Roger. Casement: The flawed hero. Routledge \& Kegan Paul, 1984. 1997.

(ed). Roger Casement's Diaries, 1910: The black \& the white. London: Pimlico,

Taussig, Michael. Shamanism, Colonialism, and the Wild Man: a study in terror and healing. The University of Chago Press, 1991. 
Todorov, Tzvetan. Mikhail Bakhtin: The Dialogical Principle. University of Minnesota Press, 1984.

Recebido em: 08/06/2018

Aceito em: 27/08/2018 